\title{
PENGARUH SISTEM PENILAIAN KINERJA DAN INTELLECTUAL CAPITAL TERHADAP EFEKTIVITAS IMPLEMENTASI TOTAL PERFORMANCE SCORECARD DAN IMPLIKASINYA DALAM MENINGKATKAN KUALITAS JASA (Studi Pada Perbankan Syari'ah di Pulau Jawa)
}

\author{
Siti Maghfiroh \\ Fakultas`Ekonomi Universitas Jenderal Soedirman \\ Purwokerto \\ Intan Imam Sutanto \\ Sekolah Tinggi Cendekia Karya Utana \\ Semarang
}

\begin{abstract}
Improvement of service quality for banking institutions is one of the key factors in the competition international in this globalization era Total Performance Scorecard (TPS) is an approach to improvement the quality continually from every business aspect and organization totality. In its application, TPS implementation is affect another factors that is: intellectual capital and performance appraisal performance to increase service quality and performance of higher education. The purpose of this research are analyze and verify the effect of performance appraisal system and intellectual capital toward total performance scorecard and their implication of toward service quality at Islamic banking in Indonesia. The type of this research is descriptive and verification, while the method used both descriptive and verification survey. The data will be analyzed by using descriptive analysis, simple regression and multiple regression. The results indicate that: 1) performance appraisal system and intellectual capital have significant effect toward implementation of total performance scorecard, 2) implementation of total performance scorecard have significant effect toward service quality at Islamic banking in Java,
\end{abstract}

Keywords: Total Performance Scorecard, Performance Appraisal System, Intellectual Capital, Service Quality and Islamic Banking 


\section{A. Pendahuluan}

\section{Latar Belakang Penelitian}

Perkembangan perbankan syariah di Indonesia berkembang pesat. Berkembangnya perbankan syariah di Indonesia diawali adanya fatwa dari organisasi keislaman di Indonesia yang mengharamkan bunga bank. Perkembangan tersebut mendapat dukungan dari Pemerintah dengan dikeluarkannya regulasi terbaru yaitu UU No.21 Tahun 2008, yang mengatur secara khusus mengenai perbankan syariah melalui. Begitu pula Bank Indonesia sebagai otoritas moneter juga turut mendukung dan mendorong perkembangan perbankan syariah. Berdirinya perbankan syari'ah telah menjadi tolak ukur keberhasilan perkembangan ekonomi syariah di indoneasia. Selain itu pesatnya perkembangan tersebut tidak terlepas dari keberhasilan perbankan syari'ah dalam menghadapi krisis moneter yang terjadi baik tahun 1998 maupun tahun 2008 dibandingkan perbankan konvensional.

Sebagaimana fungsinya Bank adalah lembaga keuangan (financial institution) yang berfungsi sebagai perantara keuangan (financial intermediary) antara pihak yang kelebihan dana (surplus unit) dan pihak yang kekurangan dana (deficit unit). Melalui jasa bank, kelebihan dana tersebut disalurkan kepada pihak-pihak yang memerlukan. Dengan demikian dapat dikatakan bahwa hal yang terpenting bagi bank dalam menjalankan bisnisnya adalah nasabah (baik penabung maupun pminjam) karena bank hanya menjalankan fungsinya sebagai perantara. Untuk meningkatkan loyalitas nasabah salah salah satu hal yang mutlak dilakukan oleh bank adalah memberikan layanan yang berkualitasbagi para nasbahnya.

Dengan perkembangan bank syari'ah yang semakin pesat sekarang ini menyebabkan persaingan antar bank syari'ah semakin ketat. Pada kondisi persaingan yang demikian ketat, bank harus memiliki satu atau beberapa dari faktor keunggulan bersaing. Menurut Porter \& Skiner (1993) dalam Chase, et al. (2001) faktor keunggulan bersaing itu salah satunya adalah keunggulan kualitas. Sehingga, kualitas jelas merupakan masalah pokok yang akan menjamin perkembangan bank syari'ah dalam meraih status di tengah-tengah 
persaingan perbankan yang semakin ketat. Sistem manajemen stratejik yang dapat memperbaiki kualitas suatu organisasi/institusi secara berkesinambungan adalah manajemen kualitas atau pendekatan Total Quality Management (TQM) (Sallis, 2006).

TQM merupakan pendekatan manajemen yang dapat memperbaiki kinerja dan efisiensi organisasi (Saylor, 1996 dalam Sodikoglu et al., 2004). Beberapa penelitian menunjukkan bahwa total quality management mampu meningkatkan kualitas produk maupun jasa. Hasil peelitian Ahire (1996), menunjukkan bahwa total quality management berpengaruh positif terhadap kualitas produk /jasa perusahaan. Sementara Hendriks \& Singhal (1997), menemukan bahwa kinerja finansial kegiatan operasi perusahaan, hasilnya menunjukkan bahwa perusahaan yang mendapatkan quality awards (proxy pelaksanaan TQM) mengalami kenaikan kinerja finansial. Akan tetapi dari beberapa penelitian ditemukan bahwa, tidak semua organisasi yang mengimplementasikan TQM berhasil meningkatkan kinerjanya (Sim \& Killough, 1998). Hasil tersebut di dukung oleh hasil penelitian Yen et al. (2002), yang menemukan bahwa bahwa dua dari tiga perusahaan yang mengimplementasikan TQM mengalami kegagalan.

Gagalnya perusahaan dalam mengimplementasikan TQM bukan dikarenakan filosoinya yang salah (Ngai dan Cheng, 1997)., tetapi selama ini diasumsikan bahwa perbaikan dan perubahan organisasi tergantung pada analisis internal dan eksternal, gambaran proses bisnis, persiapan program pengukuran dan pengkajian ulang hasil yang diukur. Apabila organisasi berhasil merumuskan dan menerapkan tujuan dan strategi yang tepat berdasarkan prosedur itu, perbaikan dan perubahan sudah pasti akan tercapai. Akan tetapi ternyata terbukti bahwa pendekatan itu tidak lagi memuaskan, karena kurangnya pemahaman manajemen akan perilaku dasar manusia. Karena pengaruh perkembangan pasar modern dan perkembangan teori manajemen baru, proses perubahan organisasi berkembang dari perbaikan kualitas (manajemen kualitas) menjadi manajemen perbaikan dan perubahan, yaitu total performance scorecard. Total Performance Scorecard mencakup sebuah filosofi dan seperangkat aturan yang membentuk dasar bagi 
perbaikan proses berkesinambungan dan perbaikan pribadi karyawan perorangan, merupakan suatu proses perbaikan sistematis, pengembangan dan pembelajaran yang berkesinambungan, bertahap dan rutin yang terpusat kepada perbaikan kinerja pribadi dan organisasi secara berkelanjutan. Perbaikan, pembelajaran dan pengembangan merupakan tiga kekuatan mendasar dalam konsep manajemen terpadu itu. Ketiganya terkait erat dan harus dijaga keseimbangannya. Total Performance Scorecard mengacu kepada sebuah cara hidup dalam organisasi, yang merupakan pengembangan dari Total Quality Management dengan menambahkan Competencies Management dan Personal and Organizational Balanced Scorecard (Rampersad, 2006). Untuk itu dalam konsep total performance scorecard dimasukkan beberapa variabel yang secara bersama-sama dengan total quality managemen berpengaruh dalam meningkatkan kualitas yaitu: personal and organizational balanced scorecard dan competence management (Rampersad, 2006).

Keberhailan implementasi total performance scorecard (TPS) itu sendiri sangat di pengaruhi oleh berbagai faktor antecedennya, dalam hal ini faktor-faktor yang mempengaruhi keberhasilan implementasi. Efektivitas strategi organisasi (sistem manajenen kualitas) dalam meningkatkan kinerja organisasi sangat tergantung pada kesesuaian antara strategi dengan lingkungannya, salah satunya adalah tenaga kerja (intellectual capital karyawan) (Balkin \& Gomez-Mejia, 1986). Selain itu juga di pengaruhi oleh faktor-faktor yang lain yaitu; sistem pengukuran kinerja. Hal ini sejalan dengan hasil temuan beberapa peneliti, bahwa kegagalan implementasi manajemen kualitas (TPS) karena tidak adanya standar penilaian kinerja karyawan (Ngai \& Cheng, 1997), selain itu dalam realita banyak perusahaan yang tidak memiliki indikator yang jelas dalam melakukan pengukuran kinerja karyawan (Nursya'bani Purnama, 2002),

Berdasarkan uraian tersebut di atas, perbankan syari'ah di Indonesia dapat meningkatkan kualitasnya melalui implementasikan total performance scorecard. Adapun alasan peneliti untuk melakukan penelitian ini adalah: (1) kualitas merupakan syarat keberhasilan dalam berbagai sektor, (2) berdasarkan beberapa hasil penelitian dapat 
ditunjukkan bahwa kualitas merupakan syarat utama bagi perbankan syari'ah untuk meningkatkan loyalitas nasabahnya.

\section{Identifikasi Dan Rumusan Masalah}

Berdasarkan latar belakang penelitian dan identifikasi masalah yang telah diuraikan di atas, maka dalam penelitian ini permasalahan dapat dirumuskan sebagai berikut:

1) Apakah Sistem penilaian kinerja berpengaruh terhadap implementasi total performance scorecard?

2) Apakah intellectual capital berpengaruh terhadap implementasi total performance scorecard?

3) Apakah implementasi total performance scorecard berpengaruh terhadap kualitas jasa?.

\section{Tujuan Penelitian}

Tujuan penelitian ini adalah:

1) Melakukan studi untuk mengkaji dan menganalisis guna mendapatkan bukti pengaruh system penilaian kinerja terhadap implementasi total performance scorecard.

2) Melakukan studi untuk mengkaji dan menganalisis guna mendapatkan bukti pengaruh intellectual capital terhadap implementasi total performance scorecard.

3) Melakukan studi untuk mengkaji dan menganalisis guna mendapatkan bukti pengaruh implementasi total performance scorecard terhadap kualitas jasa.

\section{B. Kerangka Pemikiran Dan Hipotesis}

TQM merupakan salah satu ilmu yang berorientasi pada kualitas dan merancang ulang sistem organisasi dalam mencapai tujuannya untuk memenangkan perasiangan (Fandy Tjiptono, 2000). TQM merupakan landasan kesuksesan dalam lingkungan persaingan sekarang ini. Perusahaan manufaktur dan jasa, skala besar dan kecil telah menemukan fakta bahwa perhatian kepada kualitas dapat memiliki dampak yang signifikan terhadap sasaran perusahaan. Banyak organisasi yang memperoleh keberhasilan karena menerapkan total quality management. Reisperger \& Daniel (1991) dalam Mathews, et. Al. (2001) menyebutkan bahwa total quality management efektif dalam menghasilkan peningkatan kualitas dan mengurangi biaya. 
Beberapa usaha secara empiris telah dilakukan untuk menemukan hubungan antara implementasi total quality management dengan prestasi kualitas. Flynn, et al. (1995) menemukan hubungan antara praktek total quality management dengan prestasi kualitas pada tingkat pabrik. Brah et al (2002), menemukan adanya hubungan positif yang kuat antara konstruk manajemen kualitas dengan kinerja kualitas, dan ada hubungan positif yang kuat antara kinerja kualitas dan kepuasan konsumen. Daniel I. Prajogo \& Sohal (2003), TQM berhubungan secara signifikan dengan kinerja kualitas. Daniel I. Prajogo (2005), menunjukkan adanya pengaruh praktek TQM terhadap kinerja kualitas pada perusahaan manufaktur dan jasa. Dan pengaruh praktek TQM terhadap kinerja kualitas antara perusahaan manufaktur dan jasa tidak berbeda. Sakthivel \& Raju (2006), menemukan bahwa implementasi TQM berpengaruh terhadap hasil kualitas jasa dan hasil kualitas jasa berpengaruh terhadap kepuasan konsumen. Sakthivel et al. (2005), menunjukkan bahwa institusi yang bersertifikasi ISO berkembang ke arah implementasi TQM dan menawarkan kualitas pendidikan yang lebih baik dari pada institusi yang non ISO dan ada hubungan yang signifikan antara implementasi TQM dengan kepuasan mahasiswa terhadap kinerja akademik dan kualitas jasa pendidikan.

Akan tetapi dari beberapa penelitian ditemukan bahwa, tidak semua organisasi manufaktur yang mengimplementasikan TQM berhasil meningkatkan kinerjanya (Sim \& Killough, 1998). Entin (1994) dalam Baldwin (2002) menemukan bahwa 5 dari 10 institusi pendidikan yang telah mengimplementasikan TQM, menghentikan karena mengalami kegagalan. Kegagalan tersebut karena selama ini diasumsikan bahwa perbaikan dan perubahan organisasi tergantung pada analisis internal dan eksternal, gambaran proses bisnis, persiapan program pengukuran dan pengkajian ulang hasil yang diukur. Apabila organisasi berhasil merumuskan dan menerapkan tujuan dan strategi yang tepat berdasarkan prosedur itu, perbaikan dan perubahan sudah pasti akan tercapai. Akan tetapi ternyata terbukti bahwa pendekatan itu tidak lagi memuaskan, karena kurangnya pemahaman manajemen akan perilaku dasar manusia. Karena pengaruh perkembangan pasar modern 
dan perkembangan teori manajemen baru, proses perubahan organisasi berkembang dari perbaikan kualitas (manajemen kualitas/total quality management) menjadi manajemen perbaikan dan perubahan (Total Performance Scorecard) (Rampersad, 2006).

Total performance scorecard (TPS) mencakup sebuah filosofi dan seperangkat aturan yang membentuk dasar bagi perbaikan proses berkesinambungan dan perbaikan pribadi karyawan perorangan, merupakan suatu proses perbaikan sistematis, pengembangan dan pembelajaran yang berkesinambungan, bertahap dan rutin yang terpusat kepada perbaikan kinerja pribadi dan organisasi secara berkelanjutan. Perbaikan, pembelajaran dan pengembangan merupakan tiga kekuatan mendasar dalam konsep manajemen terpadu itu. Ketiganya terkait erat dan harus dijaga keseimbangannya. Total Performance Scorecard mengacu kepada sebuah cara hidup dalam organisasi, yang merupakan pengembangan dari Total Quality Management. Untuk itu dalam konsep total performance scorecard dimasukkan beberapa variabel yang secara bersama-sama dengan total quality managemen berpengaruh dalam meningkatkan kualitas yaitu: personal and organizational balanced scorecard dan competence (Rampersad, 2006). Strategi TPS merupakan strategi manajemen untuk meningkatkan kualitas jasa.

Personal balanced scorecard dan organizational scorecard mencakup misi, visi, peran kunci, faktor penentu keberhasilan, tujuan, tolak ukur kinerja, target, tindakan perbaikan pribadi dan tindakan perbaikan organisasi (Kaplan \& Norton, 2000). Hal itu meliputi perbaikan berkesinambungandari ketrampilan dan perilaku pribadi, dengan focus pada kesejahteraan dan keberhasilan pribadi (personal balanced scorecard), Sementara itu, organizational balanced scorecard meliputi perbaikan dan pengendalian proses bisnis yang berkesinambungan, serta pengembangan strategi yang terfokus kepada pencapaian daya saing bagi perguruan tinggi. Dalam personal and organizational balanced scorecard dibutuhkan adanya keseimbangan yang efektif antara kepentingan karyawan perorangan dan kepentingan organisasi, karyawan akan bekerja dengan komitmen yang lebih besar untuk 
pengembangan organisasi. Menurut Stephen Covey (1993) dalam Rampersad (2006) bahwa kebutuhan pribadi dan kebutuhan organisasi harus diselaraskan untuk produktivitas yang lebih tinggi, kebutuhan pribadi akan membentuk perilaku seseorang dan mendorong produktivitas seseorang dalam meningkatkan kinerjanya. Sementara itu, Competence Management meliputi proses pengembangan berkesinambungan dari potensi manusia di dalam organisasi. Tujuan Competence Management adalah secara berkesinambungan memberikan kinerja tebaik dengan masyarakat yang termotivasi dan maju. Fokusnya ada pada pengambangan karyawan secara maksimal dan optimalisasi potensi mereka untuk mencapai tujuan organisasi melalui peningkatan kualitas sebagaimana diinginkan oleh pelanggan. Competence Management melibatkan pengembangan kemampuan yang terkait dengan pekerjaan; kumpulan informasi, pengalaman, ketrampilan, sikap, standar, nilai, pandangan dan prinsip-prinsip (pengetahuan) yang terpusat kepada penyelesaian ahli (expert fullfilment) tugas. Disini yang terpenting adalah siklus pengembangan, yang terdiri atas tahap-tahap berikut; perencanaan hasil, pelatihan, penilaian, dan pengambngan kemampuan berorientasi jabatan (Rampersad, 2006). Menurut Rampersad (2006) bahwa, jika ambisi pribadi seorang karyawan dilibatkan, maka ia akan bekerja dan berfikir menurut ambisi organisasi yang menjadi ambisi bersama dan pada akhirnya akan menumbuhkan motivasi, kreativitas, komitmen karyawan untuk meningkatkan kualitas hasilnya kerjanya. Dalam penelitian ini total quality management di perluas menjadi total performance scorcard.

Agar implementasi total performance scorecrd (TPS) dapat meningkatkan kualitas secara efektif, maka dalam implementasinya memerlukan perubahan mendasar pada infrastruktur organisasional, meliputi; sistem penilaian kinerja (Sim \& Killough, 1998). Sistem penilaian kinerja sering digunakan sebagai mekanisme untuk memotivasi dan mempengaruhi perilaku karyawan dalam berbagai cara yang akan memaksimalkan kesejahteraan pada keduanya yaitu; organisasi dan karyawan (Alles, et al., 1995). Keberhasilan implementasi 
TPS juga tergantung pada kontribusi sumber daya manusianya, karena implementasi TPS juga menekankan pada keterlibatan karyawan.

Sistem penilaian kinerja adalah penilaian secara akurat mengenai kinerja pekerjaan karyawan agar perilaku mereka dapat diarahkan pada pencapaian tujuan organisasi (Kleiman, 1997; 99). Hasil penilaian kinerja digunakan untuk menentukan besarnya penghargaan. Agar penghargaan yang ada dapat memberikan kepuasan bagi karyawan, maka harus ada indikator sistem penilaian kinerja yang tepat (Nursya'bani Purnama, 2000). Sebagaimana hasil penelitian Chang \& Sinclair (2003) bahwa efektifitas implementasi manajemen kualitas (TPS) dalam meningkatkan kualitas mensyaratkan adanya perubahan sistem penilaian kinerja. Hal ini didukung oleh Ittner \& Larcker (1995), semakin intensif penggunaan sistem penilaian kinerja dan pemberian insentif berdasarkan kinerja mempunyai hubungan (asosiasi) dengan kinerja karyawan dalam peningkatan kualitas, sehingga tujuan implementasi total performance scorcard akan tercapai. Hal tersebut diperkuat oleh Wruck \& Jensen (1998) yang menyatakan bahwa efektifitas implementasi manajemen kualitas memerlukan perubahan dalam sistem penilaian kinerja. Beberapa peneliti menyatakan bahwa kinerja perusahaan yang rendah, disebabkan oleh kegagalan perusahaan dalam penentuan sistem penilaian kinerja (Banker et. al, 1993).

Selain sistem penilaian kinerja adalah satu kunci keberhasilan implementasi total performance scorcard dalam meningkatkan kualitas jasa yang disediakan oleh perguruan tinggi untuk mencapai keunggulan kompetitif yang diharapkan, sangat tergantung pada sumber daya manusia yang berada di dalamnya dalam hal ini yaitu; intellectual capital. Intellectual capital (IC) sebagaimana didefinisikan oleh Burr \& Girrardi (2003) merupakan perkalian antara komitmen, kompetensi dan pengendalian pekerjaan. Komitmen dan kompetensi merupakan unsur dari modal intelektual yang melekat pada modal manusia (human capital) sedangkan pengendalian pekerjaan (job control) termasuk modal struktural (structural capital). Pekerja yang memiliki kompetensi dan komitmen organisasi tinggi tidak akan menghasilkan kinerja optimal jika pekerja tidak diberikan kebebasan, keleluasaan, dan kemandirian dalam 
mengendalikan pekerjaannya baik yang mencakup keputusan inti berkenaan dengan pekerjaan, kerangka waktu, maupun isi yang berhubungan dengan substansi keputusan. Rumarapu, et al., (1993) menemukan bahwa kualitas hasil kerja karyawan meningkat maka kinerja organisasi juga akan meningkat. Sebaliknya kurangnya komitmen karyawan dapat menghambat penerapan total quality management (Ngai \& Cheng, 1995). Jackson (2004), menunjukkan bahwa Komitmen karyawan adalah elemen penting dalam kualitas total, karyawan dengan komitmen yang kuat diharapkan dapat membentuk work desain yang dapat memberikan kapabilitas untuk melakukan apapun untuk mencapai kualitas yang diharapkan. Karyawan selain dituntut untuk memiliki komitmen dan kompetensi, juga dibutuhkan adanya pengendalian pekerjaan yang baik. Pengendalian pekerjaan berpengaruh positif terhadap kinerja individu karyawan. Sebagaimana hasil penelitian Batt (1999) bahwa karyawan yang memiliki kebebasan dalam mengatur pekerjaannya dan berpartisipasi dalam perbaikan kualitas akan mencapai kualitas jasa yang lebih tinggi dibandingkan dengan mereka yang tidak memiliki kebebasan.Dari uraian tersebut di atas, kerangka konseptual antar variabel dapat digambarkan berikut ini:

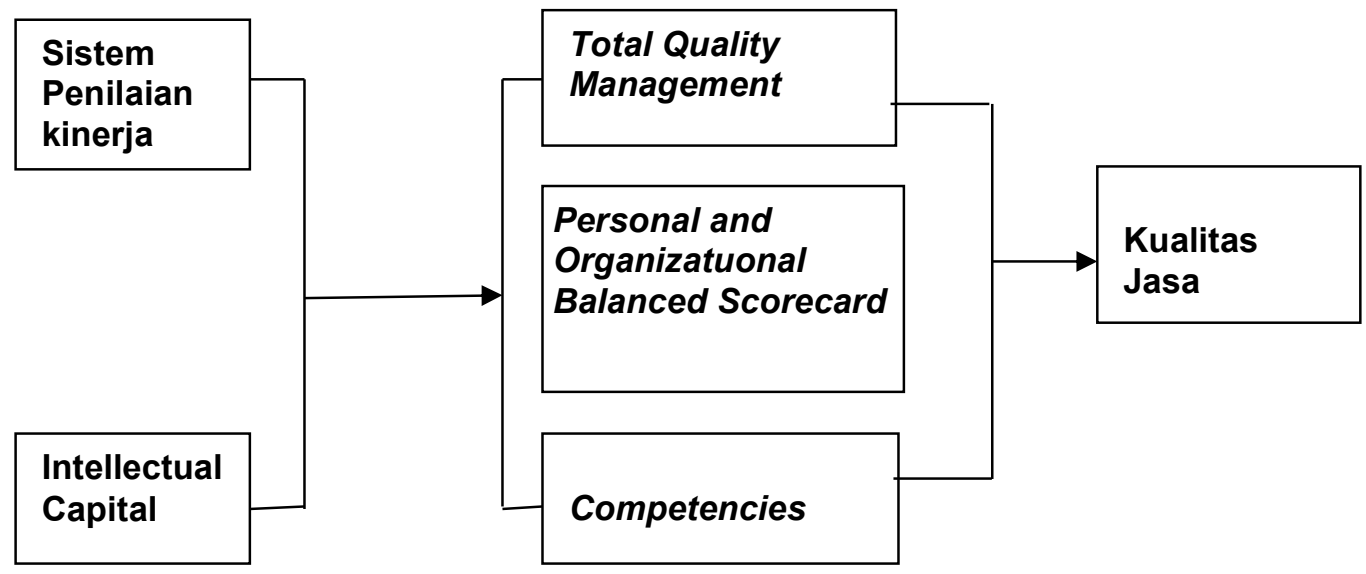

Gambar 1

Kerangka Konseptual Antar Variabel 
Berdasrakan kerangka pemikiran di atas, maka dapat dirumuskan hipotesis sebagai berikut:

1. Sistem penilaian kinerja berpengaruh terhadap implementasi total performance scorecard

2. Intellectual capital berpengaruh terhadap implementasi total performance scorecard

3. Implementasi total performance scorecard berpengaruh terhadap peningkatan kualitas jasa

\section{Metode Penelitian}

\section{Metode Pengumpulan Data}

Populasi dalam penelitian ini adalah beberapa Bank umum syari'ah (BUS) dan BPRS syari'ah di Pulau Jawa. Metode penelitian dalam penelitian ini adalah metode survey dengan menggunakan kuesioner. Kuesioner implementasi total performance scorecard, sistem penilaian kinerja dan intellectual capital diberikan kepada karyawan, sedangkan kuesioner kualitas jasa diberikan kepada nasabah di beberapa BUS dan BPRS di Pulau Jawa yang terpilih menjadi responden.

\section{Operasionalisasi Variabel Penelitian}

Dalam penelitian ini, variabel-variabelnya dapat dijabarkan berikut ini:

a. Variabel Bebas (independent variable)

(1) Sistem penilaian kinerja yaitu: efektivitas sistem penilaian kinerja yang dilaksanakan oleh perguruan tinggi untuk menilai kinerja karyawan, dengan indikator (Morgan, 2000): kepuasan terhadap sistem penilaian kinerja

(2) Intellectual capital yaitu: interaksi antara kompetensi, komitmen dan pengendalian pekerjaan karyawan. Adapun uraian masingmasing sub-variabel adalah sebagai berikut:

> Kompetensi merupakan kemauan dan kemampuan karyawan yang terbentuk dari sinergi antara watak, konsep diri, motivasi internal, serta kapasitas pengetahuan kontektual.

$>$ Komitmen merupakan tingkat keterikatan dan keinginan karyawan untuk secara terus-menerus berpartisipasi aktif pada organisasi. 
$>$ Pengendalian kerja merupakan pengembangan aktivitas dan kreativitas karyawan untuk dapat secara bebas, menggunakan kapabilitas yang dimilikinya.

b. Variabel antara (intervening variable)

- Total performance scorecard merupakan implementasi Total Quality Management, Competencies Management dan Personal and Organizational Balanced Scorecard di BUS dan BPRS di Pulau Jawa, yang terdiri dari:

> Total Quality Management, perbaikan terus menerus, yang melibatkan semua karyawan di setiap jenjang organisasi untuk mencapai kualitas yang prima dalam semua aspek organisasi melalui proses manajemen

> Competencies Management, kemampuan manajemen meliputi; kumpulan informasi, pengalaman, ketrampilan, sikap, standar, nilai, pandangan dan prinsip-prinsip (pengetahuan) yang terpusat kepada penyelesaian tugas (expert fullfilment).

$>$ Personal and Organizational Balanced Scorecard, ketersediaan misi, visi, peran kunci, faktor penentu keberhasilan, tujuan, tolak ukur kinerja, target, tindakan perbaikan pribadi dan tindakan perbaikan organisasi yang sesuai dengan organisasi.

c. Variabel terikat (dependent variable)

- Kualitas jasa yaitu: penilaian nasabah terhadap bank atas kesesuaian jasa yang disediakan oleh bank sebagaimana diharapkannya.

\section{Metode Analisis Data}

\section{a. Pengujian Validitas Dan Reliabilitas Instrumen}

Uji validitas dilakukan dengan analisis item. Dari hasil pengujian menunjukkan bahwa semua item pertanyaan valid. Untuk melakukan uji reliabilitas instrument menggunakan rumus Cronbach Alpha. Dari hasil pengujian menunjukkan bahwa kuesioner adalah reliabel.

\subsubsection{Uji Hipotesis}

Semua data yang diperoleh pada saat penelitian menggunakan skala ordinal, maka sebelum pengujian data akan ditransformasi ke data 
interval dengan menggunakan method of successive interval. Adapun paradigma penelitian secara lengkap dapat digambarkan sebagai berikut:

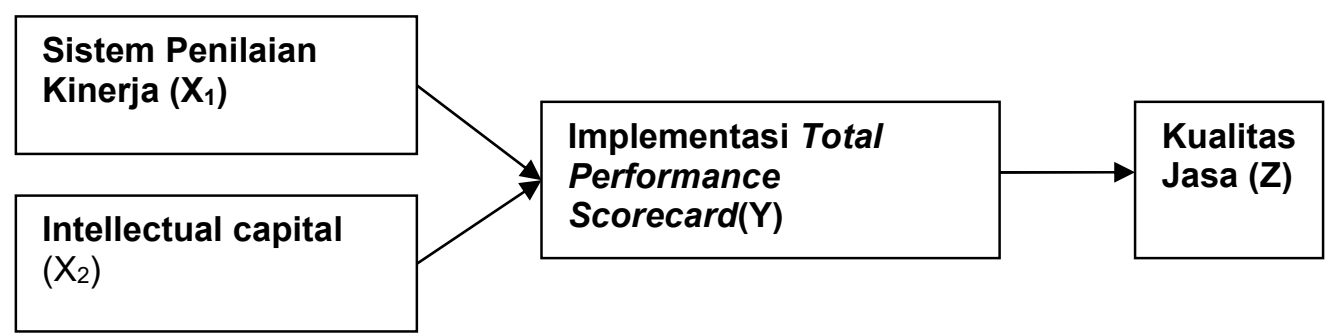

Gambar 2

Paradigma Penelitian Secara Keseluruhan

Sebelum uji hipotesis dilakukan semua data akan diuji normalitas data dan uji asumsi klasik.

\section{Uji Hipotesis 1 dan 2}

Berbagai Variabel dalam hipotesis penelitian 2 sebagai berikut:

$\mathrm{X}_{1} \quad=$ Sistem penilaian Kinerja

$\mathrm{X}_{2}=$ Intellectual capital

$\mathrm{Y} \quad=$ Implementasi total performance scorecard

Untuk uji hipotesis penelitian 1 digunakan uji reresi dengan persamaan sebagai berikut:

$Y=\beta_{0}+\beta_{1} X_{1}+\beta_{2} X_{2}+e$

Adapun hipotesis penelitian 2 jika dinyatakan dalam hipotesis statistik adalah:

$\mathrm{H}_{0} \quad: \beta_{0}=\beta_{1}=\beta_{2}=0$

(sistem penilaian kinerja dan intellectual capital tidak berpengaruh terhadap implementasi total performance scorecard)

$\mathrm{H}_{\mathrm{a}}: \beta_{1} \neq \beta_{2} \neq 0$

(sistem penilaian kinerja dan intellectual capital berpengaruh terhadap implementasi total performance scorecard)

\section{Uji Hipotesis 3}

Untuk uji hipotesis penelitian 2 digunakan uji reresi dengan persamaan sebagai berikut:

$$
Z=\beta_{0}+\beta_{1} Y+e
$$


$\mathrm{Z} \quad=$ Kualitas jasa

$\mathrm{Y} \quad=$ Implementasi Total Performance Scorecard

Untuk hipotesis 3 digunakan uji regresi Sederhana

Hipotesis penelitian 2 jika dinyatakan dalam hipotesis statistik adalah :

$\mathrm{H}_{0} \quad: \beta_{1}=0$

(Implementasi Total Performance Scorecard tidak berpengaruh terhadap Kualitas Jasa)

$\mathrm{H}_{\mathrm{a}} \quad: \beta_{1} \pm 0$

(Implementasi Total Performance Scorecard berpengaruh terhadap Kualitas Jasa)

\section{Hasil Dan Pembahasan}

1. Pengaruh Sistem Penilaian Kinerja Terhadap implementasi Total Performance Scorecard (TPS)

Hasil $\mathrm{t}$ test untuk sistem penilaian kinerja menunjukkan bahwa nilai $\mathrm{t}$ hitung sebesar 3.863 dengan probabilitas signifikansi sebesar 0.000, jauh di bawah nilai $a=0.05$, dengan demikian terbukti bahwa sistem penilaian kinerja berpengaruh terhadap efektifitas implementasi total performance scorecard.

Hasil penelitian ini mendukung hasil terdahulu (Itner \& Larcker, 1995; Wruck \& Jensen, 1998; Chang \& Sinclair, 2003) . Berdasarkan hasil penelitian pada BUS dan BPRS di Pulau Jawa dan didukung hasil penelitian terdahulu dapat dikatakan bahwa efektifitas implementasi TPS dipengaruhi oleh sistem penilaian kinerja karyawan yang memadai. Keberhasilan implementasi TPS juga tergantung pada kontribusi sumber daya manusia. Sebagaimana dinyatakan oleh Schonberger (1994) dalam Gaspersz (2001), agat TPS dapat berhasil diimplementasikan dan diinstitusionalisasikan, dibutuhkan perubahanperubahan dalam praktek manajemen sumber daya manusia. Praktekpraktek manajemen sumber daya manusia tidak bebas sendiri, tetapi terkait dengan paket total quality management dan harus selaras dengan perubahan-perubahan proses. Perubahan dibutuhkan salah satunya dalam hal penilaian kinerja karyawan. Di dalam model total performance scorecard peranan penilaian kinerja merupakan motivator terpenting bagi 
karyawan untuk meningkatkan kinerjanya dalam mencapai sasaran perusahaan. Penilaian kinerja tidak langsung menghasilkan total quality, akan tetapi apabila penilaian kinerja tidak ada atau ada tetapi tidak memuaskan karyawan, maka akan mengakibatkan hilangnya keyakinan karyawan terhadap nilai riil kualitas dan kontribusi mereka untuk memperbaiki kualitas. Oleh karena itu, bagi Bank yang akan mengimplementasikan total performance scorecard harus melakukan pendekatan penilaian kinerja apabila ingin sukses dalam menerapkan sistem tersebut.

\section{Pengaruh Intellectual Capital Terhadap Implementasi Total Performance Scorecard}

Hasil $\mathrm{t}$ test sistem penghargaan menunjukkan bahwa nilai $\mathrm{t}$ hitung sebesar 2.608 dengan tingkat signifikansi 0.012 lebih kecil dari a $=0.050$. Berdasarkan hasil perhitungan dan pengujian hasil penelitian, menunjukkan bahwa intellectual capital berpengaruh terhadap implementasi total performance scorecard.

Hasil penelitian ini menolak H0, dengan demikian hasil penelitian ini menunjukkan bahwa implementasi total performance scorecard dipengaruhi oleh intellectual capital karyawan. Hasil penelitian ini mendukung hasil penelitian Jackson (2004), Cruickshank, (2003), Ahmad \& Schroeder (2002), berdasarkan hasil penelitian ini dan dengan didukung oleh hasil penelitian-penelitian terdahulu dapat dikatakan bahwa efektifitas implementasi total performance scorecard di pengaruhi oleh intellectual capital (kompetensi $\mathrm{x}$ komitmen $\mathrm{x}$ pengendalian kerja) karyawan yang tinggi

Salah satu kunci keberhasilan implementasi total performance scorecard dalam meningkatkan kualitas jasa yang disediakan oleh BUS dan BPRS untuk mencapai keunggulan kompetitif yang diharapkan, sangat memerlukan dukungan dari sumber daya manusia yang ada di dalamnya. Selain merupakan asset organisasi yang paling vital, sumber daya manusia juga merupakan pelanggan internal yang menentukan kualitas akhir suatu produk/jasa dan organisasi. Oleh sebab itu, sukses tidaknya implementasi total performance scorecard sangat ditentukan oleh dukungan yang diberikan oleh karyawan melalui; kesediaannya (komitmen), dan kompetensinya untuk secara sungguh-sungguh merealisasikannya dalam perguruan tinggi yang bersangkutan. 


\section{Pengaruh Total Performance Scorecard (TPS) Terhadap Kualitas Jasa}

Dalam penelitian ini nilai $\mathrm{P}$ value sebesar 0.00 lebih kecil dari a sebesar 0.05 , dengan demikian maka H0 ditolak, artinya implementasi total performance scorecard berpengaruh terhadap kualitas jasa. Hasil penelitian ini mendukung hasil penelitian Arawati, et al. (2000), Brah, et al. (2002), Daniel I. Prajogo \& Sohal (2003), Daniel I. Prajogo (2005), Sakthivel et al. (2005). Hasil penelitian ini menunjukkan bahwa kualitas jasa dari BUS dan BPRS tidak terjadi dengan sendirinya, tetapi harus dicapai melalui suatu usaha, salah satunya adalah melalui penerapan total performance scorecard..

Untuk meningkatkan kualitas pelayanan yang diberikan, maka bank juga harus melakukan usaha perbaikan terus-menerus guna memenuhi kualitas yang diinginkan oleh konsumen, sebagaimana dilakukan oleh organisasi bisnis yaitu melalui implementasi total performance scorecard. Implementasi total performance scorecard akan memberikan beberapa manfaat bagi BUS dan BPRS, antara lain:

- Memperkuat organisasi dan memberikan peta jalan atau arah bagi perubahan.

- Mendorong kita untuk bekerja sebagai teman dalam kelompok kerja, bukan sebagai musuh.

- Mengupayakan suatu program yang akan mengusahakan bukan hanya penanganan satu aspek saja dari perbankan, tetapi menjadi pendekatan yang holistik dan menyebabkan segala unsur perbankan mengubah cara yang mengarahkan dirinya kepada suatu perbaikan.

- Meningkatkan partisipasi setiap orang yang terlibat dalam penyelenggaraan perbankan dan usaha-usaha masyarakat.

\section{E. KESIMPULAN DAN SARAN}

\section{Kesimpulan}

Hasil penelitian ini menunjukkan bukti bahwa peningkatan kualitas jasa dipengaruhi oleh efektifitas implementasi total performance scorecard. Sementara itu efektifitas implementasi total performance 
scorecard dapat tercapai dipengaruhi oleh system penilaian kinerja dan intellectual capital karyawan.

\section{Saran}

\section{- Bagi Perbankan}

1) Untuk meningkatkan kualitas jasa dalam mengantisipasi laju era globalisasi perbankan syari'ahi di Indonesia mulai saat ini harus mengimplementasikan total performance scorecard untuk perbaikan kualitas jasanya.

2) Agar implementasi total performance scorecard mampu meningkatkan kualitas secara optimal, maka harus diperhatikan factor-faktor yang mempengaruhi implementasi TQM, yaitu: sistem penilaian kinerja dan intellectual capital.

\section{- Bagi Peneliti Selanjutnya}

Penelitian ini belum mengungkapkan seluruh variabel yang dapat mempengaruhi kualitas jasa. Peneliti selanjutnay bias memasukkan beberapa variable moderating yaitu Islamic work Ethic dan membandingkan antara BUS dan BPRS 


\section{DAFTAR PUSTAKA}

Ahire, Sanjay L. 1996. TQM Age Versus Quality: An Empirical Investigation. Production and Inventory Management journal. Vol. 37. No. 1

Alles, M.; S. M. Datar \& R. A. Lambert. 1995. Moral Hazard And Management Control In Just-In-Time Setting. Journal Of Accounting Research.

Arawati Agus.; Suresh Kumar \& Sharifah latifah Syed. Kadir. 2000. The Structural Impact of Total Quality Management on Financial Performance Relative to Competitors Through Customer Satisfaction: a Study of Malaysian Manufacturing companies. Total Quality management. Vol. 11. No. 4

Baldwin, Linda M. 2002. Total Quality Management in Higher Education : The Implications of Internal and External Stakeholder Perceptions. New Mexico State University.

Balkin, David B \& Luis R. Gomez-Mejia. 1987. Toward A Contingency Theory of Compensation Strategy. Strategic Management Journal.Vol 8.

Bailey, Duncan \& Jerome V. Bannett. 1996. The Realistic Model of Higher Education. Quality Progress. Vol. 29. No. 11

Banker, R.; G. Potter \& R. Schroeder. 1993. Reporting Manufacturing Performance Measure to Workers: An Empirical Study. Journal of Management Accounting Research.

Brah, Shaukat; Serene S. L. Tee; B. Madhu Rao. 2002. Relathionship Between TQM and Performance of Singapore Companies. The International Journal of Quality \& Reliability management. Vol. 19. No. 4

Burr, Renu \& Antonia Girardi. 2002. Intellectual Capital: More Than The Interaction of Competence $x$ Commitment. Australian Journal of Management. Vol. 27.

Chang, Hsin Hsin \& David A. Sinclair. 2003. Assessing Workforce Perception of Total Quality-Based Performance Measurement: a Case Study of a Customer Equipment Servicing Organization. TQM \& Business Excellence. Vol. 14. No. 10. 
Daniel, S. \& W. Reitsperger. 1991. Linking Quality Strategy With Management Control System: Empirical Evidence From Japanese Industry. Accounting, Organization and Society. Vol. 17.

Daniel I. Prayogo. 2005. The comparative Analysis of TQM Practices And Quality Performance Between Manufacturing And Service Firms. International Journal of Service Industry Management. Vol. 16. No. 3

Daniel I. Prajogo \& Amrik S. Sohal. 2003. The Relathionship Between Total Quality Management Practice, Qality Performance, And Inovation Performance. The International Journal of Quality \& Reliability Management. Vol. 20. No. 8

Daulat P. Tampubolon. 2001. Perguruan Tinggi Bermutu: Paradigma Baru Manajemen Pendidikan Tinggi Menghadapi tantangan Abad ke-21. Jakarta. PT. Gramedia Pustaka Utama.

Deming, W. Edward. 1981. Improvement of Quality and Productivity Through Action by Management. National Productivity Review. Vol. 1. No. 1.

Drexler Jr, John A \& Ilene K. Kleinsorge. 2000. Using Total Quality Processes And Learning Outcome Assesments to Develop Management Curicula. Journal Of Management Education. Vol. 24. No. 2.

Fandy Tjiptono. 2000. Perspektif Manajemen dan Pemasaran Kontemporer. Yogyakarta.Penerbit Andi.

\& Anastasia Diana. 2001. Total Quality Management. Yogyakarta.Penerbit ANDI.

Flynn, Barbara B.; Roger G. Schroeder \& S. Sakakibara. 1995. The Impact of Quality Management Practices on Performance and Competitive Advantage. Decision Science Vol 26.

Gaspersz, Vincent. 2003. Penerapan Total Quality Management in Education (TQME) Pada Perguruan Tinggi di Indonesia: Suatu Upaya Untuk Memenuhi kebutuhan Industri Modern. http://www.pdk.go.id/Jurnal/29/penerapan_total_quality_ma nagement.

Hendricks, Kevin B \& Vinod R. Singhal. 1997. Does Implementing an Effective TQM Program Actually Improve Operating Perfomance? 
Empirical Evidence From Firms That Have Won Quality Awards. Management Science. Vol. 43. No. 9. September.

Ichniowsski, C.K. Shaw. 1997. The Effects of Human Resource Management Practices on Productivity. The American Economic Review.

Ina Primiana. 2001. Peran Karyawan Dalam Mendorong Keberhasilan Pelaksanaan TQM di BUMN. Manajemen Usahawan Indonesia. No. 05. TH. XXX. Mei

Ittner, C \& Larcker D. F. 1995. Total Quality Management and The Choice of Information and Reward Systems. Journal for Accounting Research (Supplement).

Joetata Hadihardaja. 2000. Kebijakan Pemerintah Mengenai Perguruan Tinggi. Kopertis Wilayah IV

Kanji, Gopal. K \& Abdul Malek Bin A. Tambi. 1999. Total Quality Management in UK Higher Education Institutions. Total Quality Management. Vol. 10.

\& William Wallace. 1999. A Comparative Study of Quality Practices in Higher Education Institutions in The US and Malaysia. Total Quality Management. Vol. 10. No. 3.

Kaplan R., \& Norton, D. P. 1990. Measures For Manufacture Excellence. Boston. Harvard Business School Press.

Kotler, Philip. 1997. Manajemen Pemasaran: Analisis, Perencanaan, Implementasi dan Pengawasan. 9 ${ }^{\text {th }}$ Edition. NY.Prentice Hall Inc: Englewood Cliffs.

Malayu Hasibuan. 2000. Manajemen Sumber Daya Manusia. Jakarta. Penerbit Bumi aksara.

Maman Ukas; Edi Suryadi; Hendri Winata \& Ating S. 2003. Kualitas Jasa Kependidikan Pada Perguruan Tinggi. Manajerial. N0. 2. Januari.

Mulia Nasution. 2000. Manajemen Personalia Aplikasi dalam Perusahaan. Penerbit Djambatan

Mulyadi. 1997. Peningkatan Kualitas Pendidikan Tinggi Indonesia, Lokakarya Pemerataan Kesempatan Belajar Dan Peningkatan Kualitas Pendidikan Tinggi. Kopertis V. Yogyakarta. 26 April. 
Muse, William V., \& Bettye B Burkhalter. 1998. Restructuring Brings Quality Improvements to Auburn University. Total Quality Management. Vol. 9. No. 4/5.

Ngai, E. W. T., \& T. C. E. Cheng. 1997. Identifying Potential Barriers to Total Quality management Using Principal Component Analysis and Correspondence Analysis. The International journal of quality \& Reliability Management. Vol. 14. No. 4

Nursya'bani Purnama. 2002. Kendala-kendala Potensial Penerapan TQM. Usahawan. Vol. 03.

Papenhausen, Chris \& Walter Einstein. 2006. Insights From The Balanced Scorecard Implementing The Balanced Scorecard at a College og Business. Measuring Business Excellence. Vol. 10. No. 3

Parasuraman, A.; V. A. Zeithaml \& L. L. Berry. 1988. SERVEQUAL: A Multiple-Item Scale For Measuring Consumer Perceptions of Service Quality. Journal of Retailing.Vol. 64.

Ramarapu, N. K.; S. Mehra \& M. N. Frolick. 1993. A Comparative Analysis and Review of JIT Implementation Research. Journal of Operations Management. Vol.15.

Sakthivel, P. B. \& R. Raju. 2006. An Instrument For Measuring Engineering Education Quality From Students'Perspective. The Quality management Journal. Vol. 13. No. 3

; G. Rajendran \& R. Raju. 2005. TQM Implementation and Students'Satisfaction of Academic Performance. The TQM Magazine. Vol. 17. No. 6

Sallis, Edward. 2006. Total Quality Management In Education. Alih Bahasa oleh: Ahmad Ali Riyadi. Yogyakarta. Penerbit IRCiSoD.

Sekaran, Uma. 2000. Research Methods For Business. New York. John Wiley \& Sons. Inc.

Shim, Khim Ling \& Larry N. Killough. 1998. The Performance Effect of Complementarities Between Manufacturing Practice and Management Accounting System. Journal of Management Accounting Research. 
Sodikoglu, Esin, D.R. 2004. Total Quality Management: Context and Performance. The Journal of American Academy of Business. Cambridge. September.

Spanbauer, Stanlet J. 1995. Reactiving Higher Education With Total Quality Management: Using Quality and Productivity Concept, Techniques and Tools to Improve Higher Education. Total Quality management. Vol. 6. No. 5

Sureshchandar, G.S., Chandrasekharan \& Rajendran, R.N. Anantharaman. 2001. A Conceptual Model For Total Quality Management In Service Organizations. Total Quality Management. Vo. 12. No. 3.

Surya, D. 2001. Kita Menderita Penyakit Diploma Disease. Manajemen Usahawan Indonesia. No. 08. TH. XXX. Agustus.

Syafaruddin. 2002. Manajemen Mutu Terpadu Dalam Pendidikan: Konsep, Strategy, dan Aplikasi. Jakarta. PT. Grasindo.

Tilaar, H. A. R. 1999. Beberapa Agenda Reformasi Pendidikan Nasional : Dalam Perspektif Abad 21. Magelang. Tera Indonesia.

Ulrich, Dave. 1998. Intellectual Capital = Competence X Commitment . Management Review.

Wruck, K. H. \& M. C. Jensen. 1994. Science, Specific Knowledge and Total Quality Management. Journal of Accounting and Society. Vol. 13.

Yen, Hsiu Ju; Dennis W. Krumwiede \& Chwen Sheu. 2002. A CrossCultural Comparison of Top Management Personality for TQM Implementation. Total Quality Management. Vol. 13. No.3..

Yeung, C. M.; Paul Humphreys \& K. L. Mark. 1998. A Just-In-Time Evaluation Strategy For International Procurement, Supply Chain Management. Vol. 3.

Young, Mark; M, Sheild \& G. Wolf. 1988. Manufacturing Control and Performance: An Experiment. Accounting, Organization and Society. Vol. 13. 